\title{
Development of Cultural Counselor Competency Based On Students Creativogenic Factors
}

\author{
Alizamar Alizamar ${ }^{\mathrm{a}}$, Afdal Afdal ${ }^{\mathrm{b}}$ \\ ${ }^{a b}$ Department Guidance and Counseling, Faculty of Education, Padang State University \\ Street of Prof. Dr. Hamka Air Tawar Padang. West Sumatera, Indonesia \\ Corresponding e-mail: a alizamar@konselor.org, bafdal@,konselor.org
}

\begin{abstract}
Various efforts have been made by the government in an attempt to improve the creativity of students, both through educational programs and other programs directly. In an effort to education, in the development of that creativity can't be separated from the role of culture in the wider community who affect the mindset, flavor, pattern acts of learners itself is referred to as a creativogenic factors. Creativogenic factors characterized by attitudes and behavior in terms of aspects of the availability of means of culture, openness to stimuli culture, the process of being grown, free opportunity to the media culture, the advent of freedom and openness to stimuli culturally different and even contrasting, tolerance and interest in view of the divergent, historically social interaction and a lack of incentives, rewards or recognition as a supporter of creativity. This study aims to identify cultural competency based on students creativogenic factor was conducted descriptively on 420 Universitas Negeri Padang (UNP) students. The sample was collected using purposive random sampling. Data were analyzed descriptively to provide an overview regarding the creativogenic factor profile of UNP students. The result showed in general condition of creativegonic UNP students are in a moderate category and there are significant differencess in social environment that support the creativity of UNP student's. Implications regarding the development of the competence of multicultural counselors are discussed further.
\end{abstract}

Keywords: Cultural Counselor Competencies, Creativogenic Factor, Student Creativity

\section{INTRODUCTION}

Creativity development is an important goal of 21 st century learning. However, both educators and the public often have difficulty in fostering student creativity[1]. Creativity is considered difficult to develop because it is still regarded as properties [2], cultural barriers [3]-[8], something that is difficult to develop [9]-[10] and is linked to various aspects that exist in man [7]-[12]. Supriadi (1994) mentions that creativity is defined depending on the person who views it which can be seen from two reasons because creativity is hypothetical construct and secondly the definition of creativity depends on the basic theory that the definition of the author makes [7]. Creativity is one's ability to produce any basically new compositions, products, or ideas [3]-[5],[13]-[14],[38]. Creativity development is the responsibility of every level of education, both in primary and secondary education and in higher education.

Universitas Negeri Padang (UNP) as teacher training institute in Indonesia hinted to be one of the leading universities in
Southeast Asia in the field of science education, sports, and arts based on piety to god almighty. To realize the ideals of UNP, the academic community of UNP has organized various programs in the field of education and non-education that supports the development of students' logical and creative thinking skills.

Creativity development is actually one of the goals of national education so that learners become useful individuals, have a high competitiveness and competent in the face of real life [10],[16],[36]. However, the problem is that the education program held has not been able to increase the creativity of students significantly. Several studies in the field of education show that the formal education system in Indonesia is generally still lacking opportunities for the development of the creativity of learners, thus creating learners who only prioritize cognitive ability alone, want something instant, put forward the behavior that does not want to explore, Individuals who are weak, do not have high competitiveness. Creative ability is the ability to create ideas, recognize alternative 
possibilities, see unexpected combinations and have the courage to try something unusual [14]-[16],[36],[43]. With creativity, students are able to provide new ideas that can be applied in solving the problems it faces.

That is why creativity has an important role in technological innovation, education, business, art and other fields of science. Several studies have shown that planned and designed environmental quality has a special impact on cognitive and social behavior in the development of individual creativity [9] and considered something complex, multi-faceted concept encompassing a variety of related aspects - abilities, properties and behaviors [17],[36]-[37],[43].

The results of Alizamar \& Afdal (2014) study found that the creativity of UNP students is still in the medium category, which means that student's creativity still needs to be developed in all aspects [16]. Student's creativity development is not only done in the form of creativity development program alone, but also attention to cultural factors that cause individuals to be creative [26]-[28],[38]. The environmental factors that support the emergence and development of creativity are defined by Sternberg and Grigorenko as the physical, social and cultural environment in which the creative process takes place, which Arieti eventually proposes as creativogenic societies and by Simonton as the influence of domain activity), intellectual receptiveness, ethnic diversity, and political openness that ultimately leads to an individual generating an idea, a new idea [16]-[21].

Humans have an impressive ability to improve their creativity [5]. Furthermore, Arieti mentions that in creative individuals there are social environment conditions that support their creativity which is also called as creativogenic factor which is characterized by the condition: (1) the availability of cultural means, including physical means in the form Equipment or materials needed for a field and other cultural media that support the development of creativity, (2) openness to cultural stimuli, where the stimulus and cultural environment not only must be available but also must be desired and easy to obtain. Creativogenic cultures should not only pay attention to goals such as the welfare, security and defense of the physical environment; Not focused exclusively or excessively on any aspect of human life, whether religious, military, commercial or other aspects. Instead, cultural media is open to all levels of society and not to certain groups; (3) the emphasis on becoming is not just being, it means that creative humans recognize that creativity is something that is shared, something that grows, needs both the future and the present; (4) to provide free media culture for all citizens, without discrimination, this means cultural media, including the community, which provides an opportunity for everyone to develop their creativity without discriminating individuals from socioeconomic status or otherwise, including also in it provides free access to the community to be able to use and utilize the existing cultural media; (5) the emergence of freedom or at least there is only mild discrimination after experience of intense pressure and action is an incentive or challenge to the growth of creativity; (6) openness to different cultural stimuli and even contrasts; (7) tolerance and interest in divergent views, views seeking alternative answers to a problem, whereas convergent thinking leads to a possible answer to a problem; (8) the existence of interactions between meaningful individuals, this indicates the existence of historical social interactions and (9) the existence of incentives, rewards or gifts, in which incentives, rewards or prizes are not the main purpose but as reinforcing their creative behavior [16],[19]-[21].

Furthermore, this research will attempt to provide a comprehensive overview of the creativogenic factors of UNP students and possible development efforts by stakeholders of creativity development. This research is important because it is useful theoretically and practically in the framework of scientific guidance and counseling especially in developing student creativogenic factor. In more detail the benefits of theoretical and practical research, among others, can increase the repertoire of science, especially related to the development of student creativity in the framework of comprehensive guidance and counseling and develop concepts related to guidance and counseling programs, especially guidance and counseling talent and creativity development of students.

\section{METHODS}

This study aims to generate of creativogenic factors of students of UNP that will be used in the framework of creativity development and competency counselor framework. For that, the research approach used is descriptive research. The population in this research is all students of UNP registered 
in semester of January-June 2016. The sampling technique is done by purposive random sampling technique, by first calculating the sample size using Solvin formula. From the calculation of the sample size found the sample of this study amounted to 420 people. Data relating to the level of creativity of students of UNP was collected through Alat Ungkap Kreativogenic (AUKREAC)/ Creatviogenic Inventory compiled by Alizamar and Afdal (2016) [16] and creativ scale obtained from Prayitno (2000) [29]. The data analysis technique used was quantitative descriptive analysis especially for condition of student creativogenic factors. Categorization of student creativity based on ideal score, and divided into 5 (five) categories by paying equal intervals between one category with other categories, very low, low, moderate, high and very high. This category will showed the quality of students' social support environment in the development of their creativity.

\section{RESULTS AND DISCUSSION}

Creativogenic data of UNP students collected through a questionnaire consisting of 35 items of statements given to 420 respondents. From the analysis of the data obtained an average of 95.24 with the highest score is 129 while the lowest score 53.

The following table presents the students' creativogenic factors as a whole:

Table 1. Description of Creativity Factors of UNP Students N $=420$

\begin{tabular}{ccccc}
\hline Indicator & Mean & SD & Category & $\begin{array}{c}\% \text { of } \\
\text { Category }\end{array}$ \\
\hline ACM & 12,9 & 3,61 & Moderate & 30,95 \\
OCS & 5,86 & 1,41 & Very High & 33,6 \\
BNB & 13.29 & 3.38 & High & 31,4 \\
FACM & 16.29 & 2.90 & Moderate & 49,8 \\
FREE & 7.80 & 1.54 & Moderate & 52,6 \\
ECC & 8.49 & 1.63 & Moderate & 40 \\
TOL & 7.79 & 1.51 & Moderate & 51 \\
ISP & 12.77 & 2.22 & High & 46,4 \\
PIA & 9.97 & 2.33 & Moderate & 41 \\
CVC & 95.24 & 12.92 & Moderate & 48,6 \\
\hline
\end{tabular}

$\begin{array}{ll}\text { ACM } & \text { : Availability Of Cultural Means } \\ \text { OCS } & \text { : Openness To Cultural Stimuli } \\ \text { BNB } & \text { : Becoming Not only Being } \\ \text { FACM } & \text { : Free Access to Cultural Media } \\ \text { FREE } & \text { : Freedom } \\ \text { TOL } & \text { : Tolerance for in differing views } \\ \text { ECC } & \text { : Exposure to Different and Contrasting Cultural } \\ \text { Stimuli } & \\ \text { ISP } & \text { : Interaction of Significant Persons }\end{array}$

\section{PIA : Promotion Of Incentives and Awards CVC : Creativogenic Factor}

Based on Table. 1 above can be seen in general condition of creativegonic UNP students are in a moderate category with a percentage of $48.6 \%$ and is in the High category as many as 174 people with a percentage of $41.4 \%$. It shows that the creativity of UNP students is generally quite high influenced by the social environment of culture. The interesting thing is that the aspect of Openness To Cultural Stimuli is very high with the percentage of students in the category of $33.6 \%$. It reveals that the culture in the student self has an important role in the dimension of creativity. In the aspect of Becoming Not only Being and Interaction of Significant Persons shows that the creativogenic of students is in the high category with the percentage of $31.4 \%$ and $46.4 \%$, which shows that the culture in the student environment has significant interaction with people around to support Creative behavior. The same is true of the BNB aspect that makes the individual not only fixated on the results alone, but recognizes the importance of the process to achieve better creativity. Furthermore, with regard to sociocultural environment conditions that support creativity when viewed from the origin of the region (urban and rural) can be explained as follows

Table 2. Differences Description of Creativity Factors of Rural and Urban UNP Students N $=420$

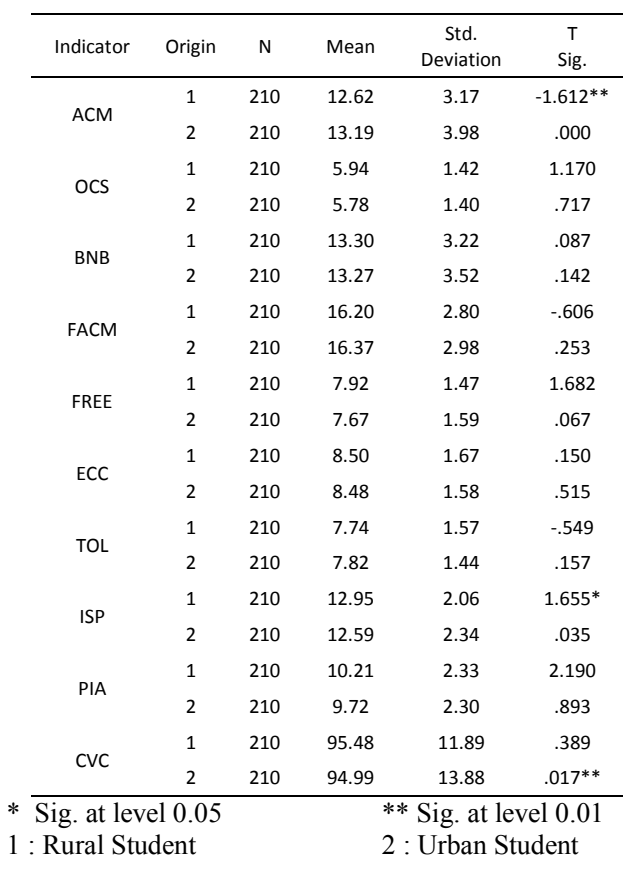


Table 2 shows the differences in cultural environmental factors that support student creativity, which can be seen from rural and urban origins, where there are significant differences in socio-cultural environments that support the creativity of UNP students, in which the social environment of rural communities has a higher mean value than With the social environment of urban communities in the development of student creativity. This difference can also be seen from the results of $t$ test that shows a statistical score of 0.389 with a significance level of 0.05 . Table 2 also gives a significant difference in the indicators studied, where there is a significant difference in the significance level of 0.05 on the ISP aspect and the significant difference at the 0.01 level in the ACM aspect. It is interesting that in other aspects outside the ISP and ACM there is no significant difference between the rural and urban social environments in the development of student creativity.

Creativity tends to occur when individual personal values interact with stimuli in the world around them and occur from an extension of cultural experience, which evolves from cultural norms and traditions [14],[32]-[33]. Researchers believe that creativity is a concept that varies from culture to culture. According to Lubart [14] declared eastern cultures tend to be less creative than their western counterparts; It is difficult to draw the distinction between creative people from diverse cultures. It is important to understand cultural and contextual factors while trying to understand creativity.

This is a major requirement in the environmental conditions of society that support the development of individual creativity. Therefore, the counselor as a whole profession, is expected to have a wide range of competencies both in terms of knowledge, attitudes and skills competencies [16],[23],[31],[34].

In terms of creativity with different cultures, counselors should have multicultural competence [23],[31]. Sue \& Sue (2012) mentions that the competence of multicultural counselors is defined as the counselor's acquisition of awareness, knowledge, and skills to behave from a diverse backgrounds, and on a organizational/society level, advocating effectively to develop new theories, practices, policies, and organizational structures that are more responsive to all groups [24]-[25].
The Association for Multicultural Counseling and Development explains the counselor competence of a culture-based that includes three domains: awareness, knowledge/understanding, and skill in awareness of one's own assumptions, values, and biases, understanding the worldview of culturally different people, developing and use of techniques and appropriate aid strategies [16],[23],[32]-[34].

Based on the results of research, competencies that must be owned by counselors in the development of student creativity are:

\subsection{Awareness Competence}

This competence is a competence concerning the consciousness of the counselor to themselves, it could be his views, his assumptions, his underlying values, his cultural conditioning products, and other consciousness's that will influence and be reflected in counseling with different races, ethnicities, and cultures. The counselor needs to rise from the unconscious to the awareness of various aspects inherent in culture. Mutuality counselors in the development of student creativity, need to realize that creativity is influenced by the client's cultural environment that can't be separated as an individual cause to be creative or not creative. Counselors need to have an awareness of the value and concern for cultural differences that will underlie the development of individual creativity. In addition, the counselor should also be aware of how his or her cultural background, experiences, attitudes, values and biases affect the pattern of the psychological relationship with the client. The counselor should also be comfortable with cultural entities (races, ethnic, cultural, and cultural) that differ between clients and themselves to show the level of professional relationships in achieving effective daily living (EDL) [3941], Counselors need to understand the various cultural characteristics that affect student creativity, including understanding the cultural structure, cultural habits, kinship patterns and their influence in the development of creativity. Counselors also need to understand the communication patterns that exist in the client and the environment [43]. 


\subsection{Knowledge/Understanding Competence}

Sue and Sue (2012) gives signs to be possessed by the counselor in this regard, namely (a) knowledge of own racial and cultural heritage and the personal and professional effects on definitions of normality-abnormality, where counselors should understand the differences that exist within themselves and their clients and do not make the difference as a barrier to professional counseling relationships (b) knowledge and understanding of how oppression, racism, discrimination, and stereotyping affect self personally and professionally. In this case the counselor needs to eliminate various stereotyping that inhibits himself and his professional work (c) knowledge of the social impact on others, i.e. how communication style differences inhibit or facilitate the counseling process and how to anticipate possible impacts, included is the counselor's understanding of the effects of positive effects on social relationships due to differences [24-25]. In terms Understanding the worldview of culturally different people competence counselor should have (a) knowledge and information of life experiences, cultural heritage, and historical background of the particular group that they are serving, (b) knowledge of how race, culture and ethnicity affect personality formation, vocational choices, manifestation of psychological disorders, help-seeking behavior, and the appropriateness or inappropriateness of counseling approaches, (c) knowledge of sociopolitical influences that impinge upon the life of racial and ethnic minorities. Furthermore, the counselor also needs competence (a) knowledge of how generic characteristics of counseling ethnocentric and class bound with some cultural values, (b) knowledge of institutional barriers that Prevent people from using mental health services, (c) knowledge of potential biases in assessment instruments), (d) knowledge of family structures, hierarchies, values and beliefs; Community characteristics, and community and family resources, (e) knowledge of the relevant discriminatory practices at social and community levels[24][25],[16],[36].

\subsection{Skill Competence}

In addition to having the competence of awareness and unity, in helping clients with creativity from different cultural backgrounds, counselors must have skills that can be used in counseling interventions. Sue \& Sue (2013) revealed that counselors need to have competency skills in terms of (a) seek educational, consultative, and training experiences to enrich understanding and effectiveness in working with culturally different populations, (b) seek to understand self as racial and cultural beings, Actively seeking a nonracist identity. In addition, counselors should also have skills in terms of (a) familiarize self with relevant and recent research on mental health / mental health disorders of ethnic and racial groups), (b) become actively involved with culturally different individuals outside the counseling setting [22]-[25],[16]. The other competencies that the counselor needs to understand are competence regarding the collaborative with all the cultural elements that influence individual creativity [44]-[45]

Furthermore, Kartadinata (2013) states that the counselor must have various competencies in the context of multicultural counseling, with the competencies referred to as RESPECTFUL, with competence in religious-spiritual racial identity $(\mathrm{R})$, ethniccultural racial background (E), sexual identity (S), psychological maturity (E), chronological-developmental challenges (C), threats to one's personal well-being (T), family history and dynamics (F), unique physical characteristics (U) and Location of residence (L). With the existence of RESPECTFUL competence is expected multicultural counselor become dignified counselor (dignified counselor) [16].

\section{CONCLUSIONS}

The results showed that overall condition of social environment of creativity of UNP students in general are in medium category. Meanwhile, if seen from the difference of cultural environmental factors that support the creativity of students from rural and urban origin, found results there are significant differences in socio-cultural environment that supports the creativity of UNP students, where the social environment of rural communities has a higher average value compared to the environment Social urban community in the 
development of student creativity, with a test score of 0.389 at the level of significance of 0.05 .

Based on the findings obtained in the study, it can be given suggestions to the parties as follows: (1) considering that creativity is not only influenced by the social environment of cultural origin, but also derived from the social condition of universities, therefore the leadership of the higher education can provide facilities and infrastructure that support the creation of a socio-cultural environment that supports the creation of students creativity development; (2) students, in order to be able to develop creativity well while still developing themselves in a positive direction, does not make the lack of facilities and infrastructure of low social environment as a barrier to student creativity; (3) the community, taking into account aspects of the social environment that develop creativity such as rewarding the achievements of other members of the community and providing cultural facilities that support the creativity of students; and (4) the next researcher is expected to take a larger sample size and enrich this research with other variables such as how the different social conditions that support student creativity in terms of local origin and so forth.

It is necessary counselor or student's must have awareness, knowledge/understanding and skill competencies in terms of awareness of individual assumptions, values and biases (awareness of one's own assumptions, values, and biases, understanding of the way individuals perceive different cultures (understanding the worldview of culturally different people, developing) as well as the proper use of techniques and assistance strategies.

\section{REFERENCES}

[1] D. Lasky, A. S. Yoo, Making Space for the Act of Making: Creativity in the Engineering Design Classroom, 2011.

[2] B. A. Weinberger, H. Iyer, \& E. A. Green, Conscious Augmentation of Creative State Enhances "Real" Creativity in Open-Ended Analogical Reasoning, pp. 1-14, 2016.

[3] M. Boden, What is creativity. Dimensions of creativity, pp. 75-117, 1994.

[4] R. Fisher, What is creativity. Unlocking creativity: Teaching across the curriculum, pp. 6-20, 2004.
[5] W. R. Weisberg, H. Gardner, A. M. Boden, \& G. Mandler,. What is creativity?. Audio Scholar, 1993.

[6] H. Takeuchi, Y. Taki, Y. Sassa, H. Hashizume, A. Sekiguchi, A. Fukushima, \& R. Kawashima, White matter structures associated with creativity: evidence from diffusion tensor imaging. Neuroimage, vol. 5, no. 1, pp.11-18, 2010.

[7] D. Supriadi, Kreativitas, kebudayaan, dan perkembangan iptek. Alfabeta, 1996.

[8] J. R. Sternberg, Psikologi kognitif. Yogyakarta: Pustaka Pelajar, 2008.

[9] G. M. Eshkaftaki, Providing Design Solutions for Children's Centers based on the Factors that Improve Creativity. European Online Journal of Natural and Social Sciences, vol. 4, no. 3, pp. 461, 2015.

[10]Alizamar, Afdal, R. Hariko, Faktor Budaya dalam Kreativitas Dan Upaya Konselor Dalam Peningkatannya. Makalah. Disampaikan pada Konvensi Nasional ABKIN 2016 di Banjarmasin tanggal 20-21 Mei 2016, 2006.

[11]M. Batey, \& A. Furnham, Creativity, intelligence, and personality: A critical review of the scattered literature. Genetic, social, and general psychology monographs, vol. 132, no. 4, pp. 355-429, 2006.

[12] C. Semiawan, S. A. Munandar, \& U. S. Munandar, Memupuk bakat dan kreativitas siswa sekolah menengah: Petunjuk bagi guru dan orang tua. Gramedia, 1984.

[13]B. E. Hurlock, Perkembangan Anak. Jakarta: Erlangga, 1978.

[14] S. Alhajri, Investigating Creativity in Graphic Design Education from Psychological Perspectives. Journal of Arts and Humanities, vol. 6, no. 1, pp. 69, 2017.

[15] T. Andriani,. Revitalisasi Naskah Syair, Sebuah solusi dalam pengembangan kreativitas mahasiswa untuk mencintai budaya lokal. Sosial Budaya: Media Komunikasi Ilmu-Ilmu Sosial Dan Budaya, vol. 11, no. 1, pp. 91-103, 2014

[16] Alizamar, Afdal, R. Hariko, Pengembangan Kompetensi Konselor Lintas Budaya Berdasarkan Faktor Kreativogenik Mahasiswa. Laporan Kemajuan Penelitian Hibah Pasca Kemenristekdikti. Tidak Diterbitkan, 2016.

[17] Jordanous, \& B. Keller, Modelling creativity: identifying key components 
through a corpus-based approach. PloS one, vol. 11, no. 10, pp. e0162959, 2016.

[18]E. Gorney, Dictionary of creativity: Terms, concepts, theories and findings in creativity research. Netslova. $r, 2007$.

[19] S. Arieti, Creativity: The magic synthesis, 1976.

[20]E. Hirschman, Individual creativity and creativogenic society. Conceptual and theoretical developments in marketing, pp. 264-280, 1979

[21] J. Khatena,. Myth: Creativity is too difficult to measure. Creativity and Giftedness, vol. 10, no. 1, pp. 63, 2004.

[22] Alizamar. Peran Perguruan Tinggi Dalam Pengembangan Kreativitas Mahasiswa: Kajian dan Praktis di Universitas Negeri Padang. Makalah. Disampaikan pada Konvensi Nasional Pendidikan Indonesia VIII tahun 2016 di UNJ Jakarta, 2016.

[23] Association for Multicultural Counseling and Development (AMCD). Multicultural Counseling Competencies. USA.

[24]D. W. Sue, \& D. Sue, Counseling the culturally diverse: Theory and practice. John Wiley \& Sons, 2012.

[25] W. D. Sue, P. Arredondo, \& J. R. McDavis, Multicultural counseling competencies and standards: A call to the profession. Journal of Counseling \& Development, vol. 70, no. 4, pp. 477-486, 1992.

[26]D. Matsumoto, Pengantar Psikologi Lintas Budaya. Yogyakarta: pustaka pelajar, 2004.

[27]D. Matsumoto, \& L. Juang, Culture and psychology. Nelson Education, 2016.

[28]U. Mundar, Pengembangan Kreativitas Anak Berbakat, 1998.

[29] Prayitno, Alat Ungkap Kreativitas (Aukreaf). Padang: Jurusan BK FIP UNP, 2000.

[30]K. Robinson, All our futures: Creativity, culture and education. Sudbury: DfEE, 2001.

[31]G. Roysircar, P. Arredondo,. N. J. Fuertes, G. J. Ponterotto, \& L. R. Toporek, Multicultural Counseling Competencies, Association for Multicultural Counseling and Development. American Counsleing
Association, 5999 Stevenson Ave., Alexandria, VA 22304, 2003.

[32]M. Spering, Current issues in crosscultural psychology: Research topics, applications, and perspectives. Universität Heidelberg, pp. 2012, 2001.

[33] P. DiMaggio, Culture and cognition. Annual review of sociology, vol. 23 no.1, pp. 263-287, 1997.

[34] M. Supriatna, Bimbingan dan Konseling Lintas Budaya. Materi PLPG PPB, FIP, UPI, 2009.

[35]E. Villalba, On creativity: Towards an understanding of creativity and its measurements. JRC Scientific and Technical Reports, 23561, 2008.

[36] KEA Eouropean Affairs. The Impact of Culture on Creativity. Directorate General for Education and Culture of European Commission, 2009.

[37] N. M. Ghufron, \& R. Risnawita, Teoriteori psikologi. Yogyakarta: Ar-Ruzz Media, 2010.

[38]B. Fesel, \& M. Söndermann, Culture and creative industries in Germany. German commission for UNESCO, 2007.

[39] Prayitno dkk, Pembelajaran melalui pelayanan BK di Satuan Pendidikan. Yogyakarta: Pramitra Publishing, 2015.

[40]Prayitno, Layanan bimbingan dan konseling. Padang: UNP Padang, 2005.

[41]Prayitno, Seri pemandu pelayanan bimbingan dan konseling di sekolah. Padang: IKIP Padang, 1998.

[42] G. J. Young, What is creativity?. The journal of creative behavior, vol. 19, no. 2, pp. 77-87, 1985.

[43] Afdal. Understanding of Non Verbal Behavior Clients and Techniques in Counseling Session. Guidena Journal, vol. 6, no. 1, pp. 33-37, 2016.

[44]Afdal, Kolaboratif: Kerangka Kerja Konselor Masa Depan. Jurnal Konseling dan Pendidikan, vol. 3, no. 2, pp. 1-7, 2015.

[45]A. Afdal, M. Surya, S. Syamsu, \& U. Uman, Bimbingan Karir Kolaboratif dalam Pemantapan Perencanaan Karir Siswa SMA. Jurnal Konseling dan Pendidikan, vol. 2, no. 3, pp. 1-7, 2014. 